\title{
THE ORIGIN OF MANAGEMENT IS SUSTAINABILITY: RECOVERING AN ALTERNATIVE FOUNDATION FOR MANAGEMENT
}

\author{
STEPHEN CUMMINGS \\ School of Management \\ Victoria University of Wellington \\ New Zealand \\ TODD BRIDGMAN \\ Victoria University of Wellington
}

\begin{abstract}
Management's origins are conventionally traced to F.W Taylor's Scientific Management - an efficiency driven worldview now superseded by a concern for sustainability. We argue the opposite: it was a concern for sustainability that made Scientific Management. Regarding this as the origin and underlying purpose of management studies could spark significant innovation.
\end{abstract}

\section{INTRODUCTION}

Scholars have lamented a dearth of substantially new ideas in management studies. This is attributed to a desire to borrow theories from other fields rather than develop unique theories; to theorizing in ways that are disconnected from the realities of management practice; to professional norms which encourage conservatism; and to the limiting institutional conditions of research in business schools. We suggest an additional proposition: that the current lack of innovation has roots in the past, or more specifically, in management research's narrow view of what in its past is relevant. Given most only encounter the history of management in introductory courses, management textbooks provide an insight into the conventional view of management's origins. Here the standard history identifies the key kernel as the assertion of a mechanisticindustrial world view and a subsequent belief that since that point, progress has come from the development of a more humanistic and organic understanding. This continuity currently culminates in views about the importance of sustainability and an organization's responsibility to the wider environment, views claimed to oppose management's classical approaches.

The primary historical figure in this narrative is Frederick Taylor. The key document is his Principles of Scientific Management. The key date, if one is provided, is 1911, the year this book was published. The origin narratives relate to management emerging as the economic and social conditions arose that both enabled greater efficiency and fueled a demand for greater efficiency. Wrapped up in this historical understanding are beliefs and practices about the basic or fundamental 'good' of management studies. If for the normal sciences the aim is to get closer to an understanding of how reality works, for medicine the preservation and improvement of physiological life, what is it for management? This used to be easy to define. Williamson and Chandler were clear that organizations emerged and persevered because the visible hand of management made them more efficient than markets. It followed that better management $=$ greater efficiency. Hence, Taylor is the 'founding father' because he is seen to be the first who theorised with this aim. As this mechanistic view moved out of step with attempts to promote a more humanistic outlook it has faded from the foreground, but other related financial measures of performance have risen and an ever-increasing amount of theorising in the field has been 
related, directly or indirectly, to achieving increases in end variable financial returns or outputs relative to inputs (March \& Sutton, 1997). Indeed, philosopher Alasdair Macintyre (1984) developed a term to express the rationality associated with this management world-view: a circular 'bureaucratic rationality', where efficiency is both the end aimed for and the means to achieve this end.

However, while Taylor and his contemporaries were investigating mechanistic efficiency as a means to an end, the loop of bureaucratic rationality had not yet closed. Efficiency was not yet viewed as the end in itself. But because management history looks back through the $20^{\text {th }}$ century 'lens' of efficiency it appears to assume, paradoxically, that Taylor both caused what Haber (1964: 52) called the "flash flood" of efficiency that hit post-1911 and was caused by it. We argue that by returning to the moments where these early management ideas were formed we might see history differently. We investigate the forces that led to SM's emergence, and how Taylor and this origin of management came into view in situ at that key moment of 1911. Our most surprising discovery is that the thing that we assume to be the opposite of, or furthest point away from, management's materialistic-mechanical starting point: sustainability: may in fact be a cause of it. And by charting a different historical point of origin and underlying purpose for management we can think beyond 'bureaucratic rationality' and determine a different aim or 'basic good' for management theorizing.

\section{A COUNTER HISTORY OF THE ORIGIN OF MANAGEMENT STUDIES}

Management studies, as we know it, emerged not as a smarter gaze was applied to understand the objective laws of management, but in response to a unique problematization in the years that preceded 1911: how to control the development of big business, which was seen to be 'running amok' in the United States. The solution was the 'conservation movement'. This created the space for the first theories of management to enter the consciousness of the mainstream. F.D. Roosevelt became President at a pivotal moment: a transition from The Gilded Age to The Progressive Era, when 'the nation suddenly 'woke up' to attend, in its own fashion, to the stress and distress of an industrial civilization" (Fink 2001: 1). His agenda put him on a collision course with the 'heroes' of the Gilded Age's rapid industrial expansion (Carnegie, Morgan, DuPont) and their 'special interests'. Originally a small subset of this agenda against special interests, Roosevelt's statements about the need for the conservation of forests would gradually provide a language that would help him counter those that began to organize against him on many fronts.

His greatest ally in these fights was Gifford Pinchot. Pinchot was ostensibly just the head of the Forestry Bureau but his influence was far wider. It was Pinchot's initiative that turned the tide when it looked like Roosevelt's attempts to take on the special interests might peter out. By the end of 1906, influential business interests in the West, and conservatives in the East were organizing against Roosevelt's attempts to curb the industrial growth that, in their minds, was a key part of the 'American Dream'. Pinchot's (1937: 262ff.) breakthrough was the invention of a "Conversation Movement" in early 1907. Realizing that the message had to be sold more effectively, Pinchot sought to "unleash... a veritable crusade of enthusiasm for conservation" in order that "a movement peculiar to federal scientists and planners [might become] deeply rooted in the minds of the public at large" (Hays, 1969: 122). Conservation became a powerful combination of applied common-sense, science and humanity that any small businessman or householder could understand. While the seed of the conservation movement may have been 
planted as a particular project relating to forestlands, it became a way to address the largest problem of the age.

Once Roosevelt's term ended, the conservation agenda became vulnerable. The main event that kept it in the media was the Pinchot-Ballinger legal case of 1910 and the representation of Pinchot's side by a Progressive Jewish lawyer from Boston named Louis D. Brandeis. While his moniker 'the people's lawyer' related to his being for the interests of ordinary people against the special interests of big business, it also reflected Brandeis' ability to skilfully market the causes he was representing through the media to get public opinion onside. After Pinchot-Ballinger, Brandeis worked on the case that led to the rise of management as a field of general importance: The Eastern Rate Case (ERC). In 1910, the Eastern Railroad Company submitted an application to the Interstate Commerce Commission seeking permission for increasing freight rates. Brandeis represented shippers opposed to the increase. Brandeis had "no thought of introducing the question of scientific management" as the case began (Brandeis in Drury, 1915: 17). This is not surprising given that SM did not yet exist. While the ideas that would be gathered under this banner had been forming for years, and the two words occurred together in Taylor's Shop Management in 1903 ("fortuitously" and without the intention of naming anything, according to Drury - 1915: 16), nobody had yet named Scientific Management. The term was developed by Brandeis for the specific purpose of winning the ERC.

Part way into the hearing, Brandeis argued that if the railroads reduced waste through new production practices then the rates could stay as they were and the railroads' bottom-line could even grow. Win-win, Brandeis argued. How could any good business person disagree? He knew this message would look better backed by men of science, or at least men sounding scientific and decided to gather a set of production consultants to discuss the case and act as witnesses (he knew Harrington Emerson and through him assembled a group including Frank Gilbreth and Henry Gantt). The consultants suggested that one idea that they were happy to associate their own ideas with was the 'Taylor system'. And after discussing alternatives they agreed that the best name for this given Brandeis' aims was the progressive sounding "Scientific Management" (Copley, 1923; Drury 1915; Nadworny, 1955).

When Brandeis made contact with Taylor to discuss the case and his potential involvement, he found him less than enthusiastic. He did not particularly like the term Scientific Management (while he did use the term after Brandeis made it popular "he continued to cherish a certain distaste for it" Copley, 1923: 372) and unusually for Taylor who generally took every opportunity to promote his ideas (Nelson, 1980), he declined Brandeis' request to testify. His jaded response is understandable given the state he was in. Taylor had retired from his work at the Midvale Steel Factory in 1907 to devote time to promoting his ideas more widely. He took on teaching and speaking assignments and provided guided tours and talks for anybody who would listen. But by 1910 he was frustrated that his system had not become as popular as he had hoped and even the American Society of Mechanical Engineers (ASME) was shunning his work.

Taylor's disposition changed, however, after Brandeis' invocation of SM achieved the desired media reaction. Soon Taylor (in Copley, 1923: 369) was writing excitedly to a supporter that "a very extraordinary thing has happened through a Boston lawyer". And Taylor became increasingly enthusiastic as a range of popular publications sought comment from the man cited by Brandeis' expert witnesses. While Taylor and Cooke drafted an article for American Magazine, Brandies won the ERC. His use of the new language of efficiency and scientific management appeared to take the railroad executives by surprise. Indeed, some exchanges indicate that they did not understand what Brandeis meant exactly by 'efficiency', the 
terminology was that new. Indeed, despite later writers seeing efficiency as a fundamental good, this sense of the word was actually still being invented in 1911. The ICC ruled in favour of Brandeis, and the railroads had to withdraw their rate increases.

Brandeis' nous and the ensuing interest in Taylor sparked a crusade for greater efficiency and management in all affairs: "an efficiency craze" hit America like a "flash flood" (Haber, 1964: 52, 10). However, it is important to recall that this interest was not the cause of scientific management - it took off in the years after the ERC was won. And despite later writers seeing Taylor as a booster of all things efficiency, he actually thought the 'efficiency craze' and 'societies' that sprang up to further it, misguided. But whatever the consequences of the ERC, Taylor acknowledged in a letter that it was Brandeis who had "w[oken] up the whole country" to his ideas. Indeed, he continued: "I have rarely seen a new movement started with such momentum as you have given this one" (Stevens Archive, Jan 9, 1911, TP98J).

Despite Brandeis not featuring in management history today, his contribution was widely credited in his own time. After losing the ERC, Railway President Willard told the New York Times (24 Feb 1911): "As I see it, there is only one thing for us to do - to put into effect the Brandeis greater efficiency system”. Popular business magazine like Moody's Magazine also see Brandeis and the conservation movement as the precursors of SM (Moody's, 1911). Early histories of management also gave Brandeis primary status. Drury's Scientific Management: A History and Criticism (1915: 15), begins: "The significance which has come to be associated with the words scientific management may be traced to an event which occurred in the later part of $1910 \ldots$... the ERC]. It happened that Louis Brandeis... assumed the leading position... against the proposed advances."

If Brandeis was the key figure in marketing SM, what did he see it serving (beyond winning the ERC)? Brandeis' personal correspondence (not published until the 1970s) reveals he saw SM as a tool for greater conservation. In November 1910, Brandeis (in Urofsky \& Levy, 1972: 386) wrote to Gifford Pinchot's brother Amos: "The time is come when you and Gifford ought to get into the railroad efficiency fight, as the greatest field for immediate conservation, and to set to work all the conservation organisations for our support." In keeping, the first line of the first book published with SM in the title ran as follows: "The efficiency movement, of which scientific management is an important factor, expresses a new philosophy that conceives of conservation as the central motive in the conduct of industry." The book, published in May 1911, was Scientific Management and Railroads by Louis Brandeis' (1911: 4). Indeed, while it may seem far-fetched today to believe that conservation gave management studies wings, the evidence is there not only in the first book on SM, but also the first line of another: Principles of Scientific Management. While many have critically analysed the content of management's founding document, its initial framing is generally overlooked: "President Roosevelt, in his address to the Governors at the White House, prophetically remarked that 'The conservation of our national resources is only preliminary to the larger question of national efficiency" (Taylor, 1911: 1).

Taylor's use of Roosevelt here was no accident. While the content of Principles is similar to Shop Management (1903), there are significant changes which connect to the issues of the day. The naming of the approach SM and allusion to science; efficiency being used more than twice as often in Principles; becoming 'more efficient' being referred to as a measure of progress; and of course, the ends of conservation and reducing waste, are not found in Shop Management. It seems that Taylor's observations of the problems of his age and the rise of the conservation movement inspired him and gave him new purpose. The archives at Stevens 
document his membership of the National Conservation Association, started by Pinchot and letters from supporters thanking Taylor for showing them the importance of "the Gospel of conservation" (August 28, 1915 W.D. Hemmerly to Kempton Taylor, Stevens Archive, 014N001). Indeed, Taylor's comment to a friend in the middle of 1911, that: "The interest now taken in scientific management is almost comparable to that which was aroused in the conservation of our natural resources by Roosevelt" (Taylor in Urwick, 1956: 60) shows how pleased he was that his work was finally gaining popularity, the importance of conservation at this juncture, and how conscious he would have been about the value of associating his work with Roosevelt and Pinchot's conservation initiative.

\section{WHY CONVENTIONAL MANAGEMENT HISTORY SEES OTHERWISE}

Historians looking back at the emergence of technical professions like engineering have defined the early $20^{\text {th }}$ century in America as an age of efficiency. Hence, it is easy now to miss that this was also "an age of conservation", that conservation was "the slogan of the day" (Bodenstar, 1918: 12, 337), and that the problematization that led to its creation provoked great intellectual ferment. If the link between conservation and the creation and acceptance of SM as the original management theory was once seen so clearly, why do we not see it now? The conservation movement burned brightly but faded fast. Conservation Congresses served as forums for national debate until 1915, but were quickly undermined by internal squabbling. Brandeis went on to great things (he became the first Jewish Justice of the Supreme Court in 1916), but his crowning achievements were in the field of law. He had little interest in becoming a leader in the field of management, and unlike Taylor, he did not have a group of consultant 'followers' who had an interest in seeing his reputation furthered.

Those who wrote the history of management in the 1940s and 50s, like Urwick and Brech, looked for antecedents of what management had come to be in their own time. Many Taylorites were still active and Urwick wrote in hagiographic style drawing a continuity of progress back from them, to Taylor, to the barons of the industrial revolution that Roosevelt and the conservation movement opposed. Management historians were more likely to examine the works of management professionals rather than law or politics and contextual socio-political factors were sifted out of the narrative. This was the baton passed to the writers of the management histories, like George, Chandler and Wren, that informed the management textbook industry in the 1970s and 80s, when the first editions of many of today's popular management texts were drafted.

George (1968) sees Taylor's contribution to management history as larger than any other. And while he works hard to link his field to the most noble of influences (e.g. Diocletian, Thomas Jefferson and Jesus) Roosevelt, Pinchot and Brandeis do not feature. Chandler does not see them or conservation as important. And a summary of his viewpoint is expressed in his (review of Wren's (1972) The Evolution of Management Thought. Wren "might have produced a more penetrating analysis if he had focussed on the changing nature of the private business enterprise in the United States... from a small shop to a giant corporation", as these were "the most critical determinants of the ways in which management thought evolved" (Chandler, 1973: 393). In other words, Wren would have done better if he had seen history as he saw it, but if one is to focus on men rather than economic changes, Chandler does agree with Wren's choice of Taylor as the "central figure". Wren does not discuss conservation, although he mentions Roosevelt and the ERC briefly. However, in recent editions Wren's history has sharpened its 
focus toward seeing Taylor as the protagonist in the birth of management. Wren's earlier editions describe lawyer Louis Brandeis as a minor contributor in furthering management thought (1972: 182-3), but by the $4^{\text {th }}$ edition this and references to books by and about Brandeis have disappeared. Brandeis fades and Taylor becomes established as the man who made management.

Adherence to this history occurs even in books that are critical of accepted management conventions. Classics like Braverman (1974) follows Chandler's history, while the more modern Morgan (2006) makes it clear that management theory begins as Taylor and his followers employ a mechanistic gaze and it then evolves increasingly organic as that initial point of origin is built upon. Shenhav (2002: 35) does paint a different history: "It is only in relation to other factors in the management movement that Taylorism can be understood in a contextual and historical perspective," he claims. But unlike our argument that the popularization of management is furthered by a network of political, legal, media and marketing forces in the moment, Shenhav traces the causes to the gradual continuity of engineering as a profession and the spread of machine efficiency as the measure of goodness.

Under Chandler's influence, the histories of management have taken increasing efficiency as a key criterion for inclusion, but, perhaps pressed for space, and a desire for an easy to follow story, they have been more enamored by Wren and George's approach of stringing together biographies of great men. Given this, whether the approach is conventional or critical, it is not surprising that as the history of management has looked backward, Roosevelt, Pinchot and Brandeis are not seen and what Taylor is said to have initiated and spread is not the gospel of conservation but, as Wren (1972: 147ff.) phrases it, "the gospel of efficiency".

\section{CONCLUSION}

The lone crazed genius F.W. Taylor, Principles of Scientific Management, the spread of the factory system, the increasing influence of the industrial revolution, modern economics and individual materialism, a mechanistic engineering mindset. These are conventionally seen as the causes of the birth of management studies: a view that corresponded with a belief that management's rationality is bureaucratic rationality where efficiency is both the end and the means to achieve it. It is not easy to get free from this set of assumptions, but what if we did think differently about management's historical constitution? The idea that the rampant development of big business was the problem, conservation the solution, and that management studies came into common consciousness due to the ensuing intellectual ferment of this particular setting, seems far-fetched now. But when one gets closer to what was being written at the time of that 'point of origin' one may be encouraged to see management differently. What if Roosevelt, Pinchot and Brandeis were taught as management pioneers? What if we recognized management becoming a subject of wide interest as a result of awakening to the perils of big business interests or capitalism run amok? What if recent interest in sustainability was not as far away from classical management as it could be, but bringing us back to where management began? In keeping, what if the aim of management, was, as Pinchot defined it for Conservation, 'the greatest good for the greatest number for the longest time'? We hope that by encouraging rethinking the historical development of management we may spur critical thinking about what management studies is here to serve and, consequently, spur innovation in management theory and practice.

\section{REFERENCES AVAILABLE FROM THE AUTHORS}

